\title{
Himalayan big bird
}

\begin{abstract}
The Himalayan Griffon (Gyps himalayensis) is a giant vulture that is the very well adapted to its environment. It consumes only dead flesh of animals. By doing so it helps to get rid of rotting carcasses in a region that offers few options for carcass disposal. Some nomadic herders that live in these regions also dispose of their dead by feeding the human remains to the vulture. The physical attributes of Himalayan Griffon are described along with photographs. Its breeding, nesting, habitat and physical characteristics are discussed. The role and impact of the Himalayan Griffon on the people living in these regions is discussed. ${ }^{1}$
\end{abstract}

Volume 3 Issue 2 - 2018

\section{Lopa Basu, Herbert W Ockerman \\ The Ohio State University, USA}

Correspondence: Herbert W Ockerman, The Ohio State University, Ohio, USA, Email ockerman.2@osu.edu

Received: January 21, 2018| Published: April 18, 2018

\section{Introduction}

To survive in the Himalayan region takes a special group of people and a special type of animal due to cold temperatures, reduced oxygen levels, little vegetation, and a short growing season in which harvest often is unsuccessful. Most of the people are herders and depend almost totally on animals to survive in this environment for their food, fuel, income, and sometimes for their pack animals and leather. Unfortunately a large percentage of newborn animals do not survive the first year. The major species that can survive and serve the human inhabititants is the yak, both domestic and wild, and which are sometimes crossed with a dairy cow. The yak supplies meat and milk, which is often made into cheese, and is used for transportation. Another useful survivor is the pashima goat, the source of cashmere. These goats have an inter coat of fine hair which is removed and woven into cashmere, which is a major source of revenue for the goat

Table I Physical Attributes of the Himalayan Griffon

\begin{tabular}{|c|c|c|}
\hline Length & $116-150 \mathrm{~cm}$ & $3.8-4.9 \mathrm{ft}$ \\
\hline Wingspan & $259-310 \mathrm{~cm}$ & $8.5-10.2 \mathrm{ft}$ \\
\hline Weight & $8-12 \mathrm{~kg}$ & I $7.6-26.5 \mathrm{lbs}$ \\
\hline Body hair & $\begin{array}{l}\text { Abundent - helps in } \\
\text { insulation }\end{array}$ & \\
\hline Feed & $\begin{array}{l}\text { Exclusively on carrion (flesh } \\
\text { from dead bodies) }\end{array}$ & \\
\hline Feed consumption time & Human, sheep-30 min; & Yak-120 min \\
\hline Flight speed & $50 \mathrm{~km} / \mathrm{hr}$ & $31 \mathrm{mph}$ \\
\hline Life span & $20-35$ years & \\
\hline \multirow[t]{2}{*}{ Voice } & $\begin{array}{l}\text { Grunting, hissing - when } \\
\text { eating and in family groups }\end{array}$ & \\
\hline & Silent in flight & \\
\hline \multirow[t]{2}{*}{ Mating } & Monogamy (one partner) & \\
\hline & Return to same nesting area & \\
\hline Color & $\begin{array}{l}\text { Body - white with pale } \\
\text { brown streaks, Feathers \& } \\
\text { tail - dark brown; head - } \\
\text { yellowish down }\end{array}$ & \\
\hline
\end{tabular}

herders who live in these regions. The goats can also supply meat but are seldom used for that purpose since the hair is much more valuable. Some species of sheep can also survive in these regions due to their wool and are often in the same herd as goats, although their wool is not as valuable as goat hair. The frozen and rocky terrain makes it difficult to bury animal and human remains. Another animal completes the life cycle and this is the big bird of the Himalayas, the Himalayan Griffon (Gyps himalayensis) vulture.

\section{Materials and methods}

Himalayan Griffon vulture is found in the Himalayan regions of India, Pakistan, Bhutan, China, Nepal, at altitudes of 1,500- 4,000 m $(4,920-13,123$ feet). The physical attributes of the Griffon are found in Table 1. Griffons have one of the largest wing spans of any bird. Their breeding and nesting habits and raising of chicks are also discussed (Figure 1) (Table 1). ${ }^{2-4}$

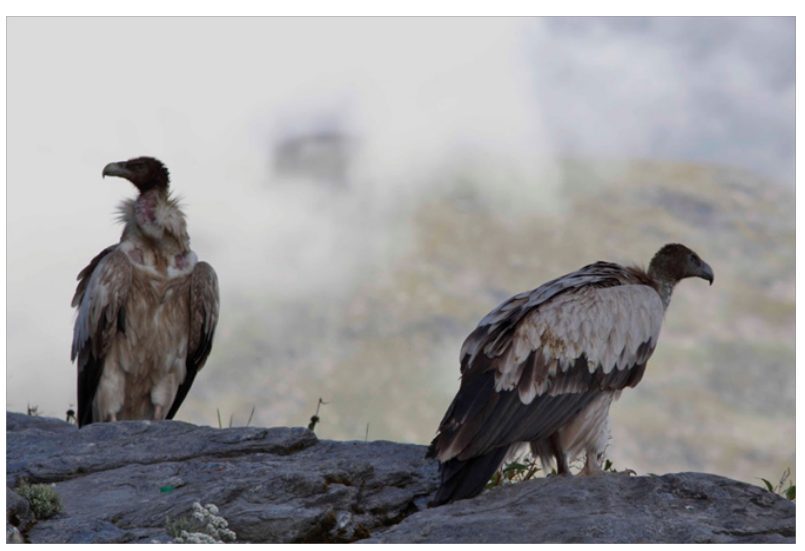

Figure I Himalayan Griffon (Photograph by first author).

\section{Results and discussion}

\section{Breeding}

Breeding season of the Himalaya Griffon starts in January and a nest is built or repaired in a cliff area, the same area each year. Several pairs may use this same general area. A single white egg with red splotches is laid in January-March. The egg is oblong in shape and measure 3-4 inches in height and 2-3 inches in width. Male and female 
vultures both incubate the egg..$^{5-7}$ The incubation period averages 56 days. The female vulture remains in the nest area and the male brings food and regurgitates the food for the female and the chick. The young bird stays in the nest for approximately for 6-7 months.

\section{Flight and feed}

The griffon takeoff starts with running and then leaping prior to getting off the ground. After a big meal sometimes digestion has to occur before it is possible to fly. The reason for this difficulty is that the bird is so heavy that even with a long wing span it takes a lot on energy to fly. Since the birds stay up most of the day they use updrafts to conserve energy. To identify prey they look for animals that are not keeping up with the herd which suggests that the animal is ill or injured. Griffons will keep track of animals sometimes for days. The vulture will descend and check on the downed animal to determine if the animal is dead. The body begins to decay upon death and bacteria and insects start to break down the tissue and this is followed by an unpleasant odor. If the tissue is consumed by a griffon this is often considered a hygienic method of disposable of dead tissue. This process conserves the nitrogen and carbon. The digestive juices of the griffon destroy harmful bacteria that may be present in the dead tissue.

\section{Feeding on human remains}

Among the nomadic herders that live in these regions, many practice Vajrayana Buddhism. The religion teaches that the dead human body is an empty vessel and therefore there is no need to preserve it. Upon the death of a herder, a sky burial is often used. The body is placed on a large flat rock. The burial involves chanting by monks and the burning of incense. The body is then disassembled and the bones broken and the flesh consumed by the griffons (Figure 2).

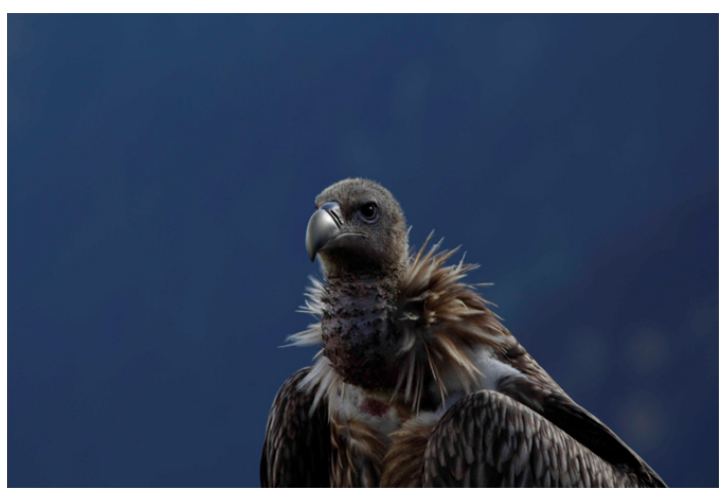

Figure 2 Close-up of Himalayan Griffon (Photograph by first author).

\section{Conclusion}

The Himalayan griffon consumes flesh of dead animals and humans in environments where burial or cremation is either not an option or not practiced. So the Himalayan griffon plays an important role in recycling the flesh of dead animals and humans.

\section{Acknowledgements}

None.

\section{Conflict of interest}

Authors declare that there is no conflict of interest.

\section{References}

1. http://www.oiseaux-birds.com/card-himalayan-griffon-vulture.html

2. https://en.wikipedia.org/wiki/Carrion

3. Gyps himalayensis Himalayan griffon. Animal diversity web; 2008.

4. Range Description. International Union for Conservation of Nature and Natural Resources; 2016.

5. Beauty of birds. Avian web; 2018.

6. Species factsheet: Gyps himalayensis. Birdlife International. 2018.

7. News IUCN Red List. Birdlife International; 2018. 